\title{
Everybody Thinks Online Participation is Great - for Somebody Else
}

\author{
A Qualitative and Quantitative Analysis of Perceptions and Expectations of Online \\ Participation in the Green Party Germany
}

\author{
Gefion Thuermer ${ }^{1}$ \\ Silke Roth ${ }^{1}$ \\ Kieron O’Hara ${ }^{2}$ \\ Steffen Staab ${ }^{2}$ \\ ${ }^{1}$ Social Sciences \\ ${ }^{2}$ Electronics and Computer Science \\ University of Southampton, UK \\ \{gefion.thuermer, silke.roth, K.M.O'Hara, S.R.Staab\} @soton.ac.uk
}

\begin{abstract}
Based on a case study from the Green Party Germany, we discuss the expectations and potential effects of the introduction of new online participation opportunities. These methods are often used in hopes of drawing in a wider group of participants, but existing literature on digital inequality suggests that this is unlikely to happen. Applying a mixed methods approach, we investigate how likely the expectations related to these new opportunities are to be met. We used semi-structure interviews to draw out what effects party members think online participation will have. We then conducted a survey asking members about their plans to change their behaviour. Comparing expectations to prospective behavioural changes, we find that the high hopes of both party members and leaders - to draw in those members who currently do not engage - are likely to be disappointed. Members who are better off, better educated, and already more active, will likely benefit more than those the party hopes to engage. We argue that this is linked to the prevailing digital divide, and that those who are targeted for more participation need to be more actively addressed to achieve broader participation.
\end{abstract}

\section{ACM Reference Format:}

Gefion Thuermer, Silke Roth, Kieron O'Hara and Steffen Staab 2018. Everybody Thinks Online Participation is Great - for Somebody Else. In WebSci'18: 10th ACM Conference on Web Science, May 27-30, 2018, Amsterdam, Netherlands. ACM, New York, NY, USA, 10 pages. https://doi.org/10.1145/3201064.3201069

\section{KEYWORDS}

Digital divide; inclusion; mobilisation; non-use; participation; political parties; reinforcement

\section{INTRODUCTION}

Online Participation in politics is a widely researched field, but most of that research focuses on citizen participation at various levels, from local to regional to states or nation states

Permission to make digital or hard copies of all or part of this work for personal or classroom use is granted without fee provided that copies are not made or distributed for profit or commercial advantage and that copies bear this notice and the full citation on the first page. Copyrights for components of this work owned by others than the author(s) must be honored. Abstracting with credit is permitted. To copy otherwise, or republish, to post on servers or to redistribute to lists, requires prior specific permission and/or a fee. Request permissions from Permissions@acm.org.

WebSci '18, May 27-30, 2018, Amsterdam, Netherlands

(c) 2018 Copyright is held by the owner/author(s). Publication rights licensed to

ACM. ACM ISBN 978-1-4503-5563-6/18/05 ..\$15.00

https://doi.org/10.1145/3201064.3201069
[1]-[4]. We are interested in how members of political parties participate in party-internal decision-making processes. The processes that parties employ to develop positions and manifestos are important, because - given sufficient success in elections - these positions may eventually lead to new legislation that governs society. Engagement in political parties is one important route for citizens to not only influence the politics of their country or place of residence, but also to learn about the democratic process, take part in public discourse [5], and improve their own efficacy [6].

Using digital technology like the internet in participation processes has raised high hopes for a broadening of democratic engagement, particularly to groups that are historically not engaged [7], [8]. Although some positive effects have been identified, particularly for young people and soft forms of engagement [4], [9], [10], there is plenty of evidence against a broadening of participation, and for continued influence of social and socio-economic inequalities on the internet [11]-[13].

This paper investigates how likely it is that the expectations related to the introduction of new online participation tools within a political party will be met. After an overview of the digital divide literature and the theory discussed in this paper (Section 2), we introduce the organisation we are studying (Section 3), and explain the reasons for and details of our mixed methods approach (Section 4). Based on interview and survey data, we discuss whether the expectations of individuals for online participation are likely to be met (Section 5). We find that they are not, and that the expectations held by party members and leaders - that online participation will benefit others - are in practice still overshadowed by the digital divide (Section 6).

\section{RELATED WORK}

In this section we discuss the theoretical foundations of the digital divide (Section 2.1), and give an overview of mobilisation and reinforcement theory, which will be used to discuss the effect of online participation methods on practical participation levels (Section 2.2).

\subsection{Digital Divide}

Access to the internet today is largely treated as a matter of course in most post-industrial societies, including Germany. Although there are some structurally weak areas, for example in Eastern Germany or Lower Bavaria, where access is limited, 92\% of the population of Germany are now connected to broadband [14], and access is no longer the key division. However, while 
access seems to become less important, other aspects have become more important. Even if people are online, the benefits they derive from using the internet differ with sociodemographic factors such as gender, age, income and education [15]. A further consideration is the skills necessary to use the technology and derive benefit from it [16]. Inequalities that exist offline have been shown to be perpetuated in the use of the internet [17]. Thus, those who are already disadvantaged offline may stay disadvantaged when they use the internet.

With regards to political participation online in Germany, the strongest explanatory factor for differences in online use is habit [12]: Only those who are already used to using the internet for a variety of activities will also adopt it for political participation. Age is important in this context, as habits form with age, and those who were older when the internet was widely adopted will be less likely to change already existing habits - though they do adopt it for some activities [18]. Benefits for those who use the internet for political participation are mostly in the area of political information and discussion, and the group that benefits most, dubbed 'digital citizens', are males in their mid-twenties, with university education, no children and low income [12]. In terms of gender as well as education, this is not surprising, as it reflects the typical party member in Germany [19], as well as the overall lower participation and representation of women in politics [20]. Age however is distinctly different: Among party members, people under 35 are underrepresented [19].

These differences are highly problematic for democratic processes: Democratic ideals generally assume some form of equal opportunity to participate. Dahl describes democracy as the "process of making collective and binding decisions" [21, p. 5], which are based on equality: If all members of a group are equal, then they all ought to have the same influence on decisions that affect them. This applies to democratic republics as well as to democratic parties and their internal processes. As it stands, participation is not equal regardless of whether it is conducted offline or online, and the question is not whether democratic participation can be achieved online or offline, but whether adding online elements to existing offline processes can improve democratic participation.

\subsection{Mobilisation \& Reinforcement}

Mobilization and reinforcement theories can be used to describe potential effects of online participation. On the one hand, mobilization theory [7] argues that with new online participation methods, more people can be drawn in, leading to broader participation. Reinforcement theory [22], [23] on the other hand states that new online participation methods will be picked up by those who are already active, thus increasing - or reinforcing - the influence they already have. We would like to add two further dimensions to this discussion: Replacement [24], [25] and Non-Use [26].

Online participation may simply replace existing offline methods, without effect on who participates, or with which intensity: Things that were previously done offline are now done online, by the same people. This effect has been described in some variations and with different terms (such as 'normalisation' [11]), but we consider 'replacement' to be the most accurate description, as we refer specifically to one type of media replacing another, without other side-effects.

Lastly, there is a risk, especially for large organisations, that online participation methods are introduced, and not used at all. Non-use has been considered with regards to internet access [26], [27], but with regards to political participation it is a new and still underdeveloped topic [11], [28]. We did find in literature as well as our own preliminary results that non-use members not using tools that have been implemented - can be a problem because these tools cost considerable amounts of resources to implement. Whether new tools are adopted by party members appears to be related to the way new platforms are introduced. This was demonstrated during the introduction of the Green Parties' internal knowledge management platform 'Wurzelwerk' in 2009, which was perceived as so unintuitive by users [29], [30], that even an eventual relaunch could not save its reputation - an experience the party is not keen to repeat.

\section{CASE STUDY: GREEN PARTY GERMANY}

Parties in Germany are governed by legislation, such as the Basic Law, which stipulates that they 'shall participate in the formation of the political will of the people' [31, Para. 21.1] and must follow democratic procedures; and the Political Parties Act [32], which stipulates that they must have a certain structure, with a general or delegate assembly at national level as the highest decision-making body, and equal voting rights for all members. This requirement to make decisions democratically and with equal rights is implemented differently in different parties [33].

In this section we will introduce the Green Party Germany as the case study we are focussing on, argue why they are a particularly good example of an organisation that attempts to introduce online participation, and give an outline of the problem the party is trying to address.

\subsection{History}

The Green Party Germany was founded in 1980, and has roots in the women's, peace, and environmental social movements [34]. It has been represented in the German Bundestag since 1981 . The party has had a strong grass-roots orientation from the very beginning, with processes designed to limit the power of spokespeople and MPs. After the German reunification, the Western Green Party merged with the Eastern 'Bündnis 90', an alliance with similar roots and intentions, which already formed a parliamentary group with the Eastern German Green Party. After the party failed to be elected into the national parliament in 1990, they softened some of the old rules that were supposed to maintain strong grass-roots [34], and formally developed wings for different ideologies. These are the 'Realos' (now Reformer), who favour pragmatism and government responsibility, and the 'Fundis', (now Linke), who favour close adherence to the parties ideals [35]. The party re-entered the German Bundestag in 1994, and formed part of the government coalition between 1998 and 2005.

Despite all of these developments, the party remains focussed on grass-roots participation. There are still regulations that prevent members from holding mandates and executive board 
positions at the same time, and a ban on members of government simultaneously holding positions in the party above the local level [36]. Members of the Green Party continue to have a stronger position in the parties' decision-making processes than in other major German parties [37]. They are typically highly educated, with $58 \%$ holding university degrees, and $37 \%$ working as public servants - both the highest proportion in all major German parties, and well above average in the population [38].

In contrast to other parties, decisions in the Green Party are largely made bottom-up, with quotas to ensure equal participation of women, as this is a founding ideal. The party leadership has a strong interest in allowing and encouraging participation in decision-making processes by the whole member base. This ideal includes allowing members to participate online, and consequently, tackling the digital divide for their internal processes. If as many members as possible should participate, they need to be enabled to do this, and none should be excluded based on gender, skills, or resources [39].

For all this, the Green Party is a 'most likely case' [40]: Given their commitment to participation and equality, if online participation can work in any political party, it should work here. If it fails here, this can give important indications to challenges that need to be addressed, wherever online participation is introduced.

\subsection{Problem Description}

Given the persistent digital divide in Germany, using the internet in party-internal processes poses a challenge: If these processes are not perceived to be as inclusive and accessible as all the other (offline) processes the party uses, that might reduce the legitimacy of their outcomes.

The party leadership wants to actively use the internet in order to draw more members into participation. A special task force [41] has developed a set of new online participation processes that the party voted to introduce at the national delegate assembly in November 2016: The 'Mitgliederbefragung' (Befragung), an online survey, which is sent to all members at least annually, and aims to bring their opinions into discussion processes in the parties bodies and task forces; and a 'Mitgliederbegehren' (Begehren), a new process similar to a petition, by which 250 members can collectively 'demand' something from the executive board. This could be a specific action, or the discussion of a topic. The Befragung has been used since 2016, and the Begehren is due to launch in 2018. Both processes are web-based, with alternative offline routes. For example, members can request a paper copy to fill in the Befragung, or send a signed fax to the parties' headquarters to support a Begehren.

The Green Party wants to achieve mobilisation and prevent reinforcement; they want to include the excluded. As discussed above, the literature on the digital divide suggests that mobilisation is unlikely to happen without specific measures to motivate currently inactive members. The inherent inequalities both in political participation, and use of the internet, as well as in benefits derived from that use, are at odds with the democratic ideal of equality in the Green Party. However, the potential benefits of internet use - speed, ease of use, low cost, and the potential to reach members that were previously not involved make its use worthwhile. The party wants to actively tackle the deterministic 'it cannot work', and find a way to overcome these inherent inequalities, so they can use the internet in a way that does not contravene their ideals.

\section{METHODOLOGY ${ }^{1}$}

To identify how members perceive online participation, and what potential it has to mobilize more members to participate, a mixed methods approach is taken, consisting of interviews, observations, and a survey. We will show, based on qualitative, semi-structured interviews and participant observations, what effects party members think online participation will have, and who they believe will benefit. We will then compare these assumptions to a dataset of survey responses among the whole member base, which gives an indication as to how members plan to change their own behaviour with these new online participation methods.

\subsection{Observations \& Interviews}

Observations were conducted during the general delegate assembly of the Green Party in Münster in November 2016, where the above described key decisions about the future of online participation were made. We focused on the debates about these decisions at the assembly, as well as following the discussion on the parties' online platform for proposals, where members exchanged arguments for and against them.

Table 1: Interview Participants

\begin{tabular}{|l|l|l|l|l|}
\hline Age & Gender & Position & $\begin{array}{c}\text { Place of } \\
\text { Residence }\end{array}$ & Wing \\
\hline $18-25$ & $\mathrm{~m}$ & 1 & City & R \\
\hline $26-35$ & $\mathrm{f}$ & 2 & City & R \\
\hline $26-35$ & $\mathrm{f}$ & 2 & Suburb & - \\
\hline $26-35$ & $\mathrm{~m}$ & 2 & City & - \\
\hline $36-45$ & $\mathrm{f}$ & 3 & City & - \\
\hline $36-45$ & $\mathrm{~m}$ & 3 & Rural & L \\
\hline $46-55$ & $\mathrm{~m}$ & 2 & Suburb & L \\
\hline $46-55$ & $\mathrm{f}$ & 1 & City & L \\
\hline $56-65$ & $\mathrm{~m}$ & 2 & Rural & - \\
\hline $56-65$ & $\mathrm{~m}$ & 1 & City & L \\
\hline $56-65$ & $\mathrm{f}$ & 3 & City & - \\
\hline
\end{tabular}

N = 11; Position: $1=$ Local Level, $2=$ State Level $3=$ =Above State Level; Wing: $R=$ Reformer, $L=L e f t$

Semi-structured interviews were conducted with participants of these debates, both online and during the assembly. Questions revolved around how they perceived democracy and participation within the party, they current participation, and whether, how and why the party should or should not use online participation methods. A total of 11 interviews were conducted. A brief overview of participants is shown in Table 1.

\footnotetext{
${ }^{1}$ All data collection and analysis was done by the first author
} 
The observations and interviews were recorded, transcribed, and used in a qualitative content analysis [42], [43]. The data was coded inductively, to generate a set of criteria that were relevant to the participants.

\subsection{Survey}

The Green Party regularly conducts online surveys among their member base - the Befragung they introduced at the assembly in Münster formalised this practice. We were given the opportunity to add some questions about participation to one of these surveys in April 2017. All party members were invited to participate in the survey. Emails were sent to everyone who had an email address registered in the party's members' database (about 84\%), and letters to those who did not. The latter were invited to respond to the survey online, rather than the survey being posted directly. All members could request a paper copy of the survey - an option which was not used at all in this instance. The survey returned just under 3500 responses, which equals a response rate of about $6 \%$.

The parties' survey focussed on the upcoming election campaign, with our questions, based on findings from the interviews and observations, circling around the current and potential future use of online participation methods. While the qualitative data focussed on general expectations and assumptions around online participation, the survey asked explicitly how members plan to change their own behaviour through these tools.

The majority of questions focussed on how members already participate (Channel), what type of activity they engage in (Activity), and how they plan to use the newly introduced online methods. We further asked them to order a set of statements about their democratic preferences, which consisted of two pairs of statements:

- All members can participate in votes

All members can participate in discussions

- All members can participate equally

All members can participate as much as possible

These were turned into binary variables for the preferred participation Type (votes/discussions) and Intensity (equally/as much as). Alongside demographic information, we also asked about their position in the party, as well as their position on the political spectrum. ${ }^{2}$

The survey data was analysed in two stages: First an exploratory factor analysis was conducted, then binary logistic regression models were generated.

\subsubsection{Factor Analysis}

Factor Analysis is used to reduce the amount of variables in the analysis, and to identify underlying factors that the data did not include explicitly [44]. The factor analysis was conducted in SPSS using principal axis factoring. Only one factor was generated (Cronbach Alpha: 0.861). It included both Activities and Channels for participation that members use, as well as their Position within the party. We use this factor as an indicator for participants' level of 'Institutional Activity'. The higher the factor score, the more members are engaged in institutional activities within the party. The individual factor loadings are shown in Table 2.

Table 2: Factor Loadings for Institutional Activity

\begin{tabular}{|l|l|}
\hline Variable & Loading \\
\hline Activity: Discussed proposals & 0.791 \\
\hline Activity: Supported proposals & 0.745 \\
\hline Activity: Attended assembly as delegate & 0.724 \\
\hline Activity: Worked in party bodies & 0.692 \\
\hline Channel: Supra-local Meetings & 0.673 \\
\hline Position & 0.651 \\
\hline Activity: Discussed relevant topics & 0.624 \\
\hline Activity: Wrote proposals & 0.566 \\
\hline Channel: Local Meetings & 0.455 \\
\hline Channel: Non-localised Meetings & 0.411 \\
\hline Channel: Social Media & 0.356 \\
\hline
\end{tabular}

A second factor, indicating the 'Propensity to Participate Online', based mainly on Age and Internet Use, was discarded as too unreliable for use, with a Cronbach's Alpha value of just 0.381 .

Due to the purpose of factor analysis - generating a new variable that summarises existing data - we consider this analysis to be part of the method, and do not provide detailed analysis of the results. More detail is given in the interpretation of the logistic regression models which use the factor (Section 5.2.2).

\subsubsection{Logistic Regression Models}

Binary logistic regression is the a suitable analysis for our survey data, since it allows prediction of non-linear dependent variables [44].

Two models were generated to identify what variables best predict members' behaviour. The dependent variables are based on participants' response "I will participate more" to the survey question "How do you think [the new participation methods] will affect your own participation?" We turned these into binary responses: 'I will participate more through Befragung': Yes/No and 'I will participate more through Begehren': Yes/No. The models, summarised in Table 3: identify which variables are significant for predictions of an anticipated increase in participation through either tool.

\section{FINDINGS \& DISCUSSION}

Based on the above described data, we found that what members expect to happen and how they expect to act personally is very different, and that the expected benefits of online participation do not appear to be likely to materialise. We will now in turn discuss the results of the qualitative data - what members expect - and the survey data - what members expect to do.

\subsection{What members expect to happen}

Participants of the assembly and interviews generally had a very positive attitude towards online participation, having experienced it as enabling themselves as well as others. They

${ }^{22}$ The full survey questions and response options can be found online at https://zenodo.org/record/1171109 
generally assume that online participation methods are currently both enabling and inhibiting for different groups. The plans that members were aware of were perceived as improvements, and the expectations were that the new processes would be more enabling than constraining. However, most participants did neither consider these processes as particularly useful for themselves, nor did they see them as hindering their own participation - although all of them were already actively using online platforms, such as mailing lists or social media, to participate. They were enthusiastic on behalf of others, but indifferent for themselves.

We found many assumptions about what online participation already does within the party, with regards to tools or processes that are already in use, such as email or Wurzelwerk. These were neither perceived as enabling nor inhibiting the participants themselves, though they assumed considerable effects in both directions for other members. For example, a member living in the suburb of a large industrial metropolis believed that online participation would help those in rural areas:

"With emails, it is a lot easier to find fifty or sixty people to support a proposal, than it was to find twenty in the past. And that is also the case for rural areas, as most of them should have internet by now."

However, a member who lived in a rural area made the experience that processes are more of a barrier in the countryside, regardless of whether they are online or offline, simply because there are fewer members, and with a smaller network, support is harder to find. Even if it were easier to recruit supporters online, because their local network is limited, so is their opportunity to reach out to others. This shows how offline inequalities are perpetuated online [17].

Experience of members sometimes confirmed (or led to) expectations for other members. For example, a member of the parties' youth organisation 'Young Greens' described how the Befragung was accessible, and thus user friendly for older members:

I think the surveys were very accessible, so that everyone, including old people, could participate. It stated clearly to ,now click this link in the next line."

This is also reflected in the view of a state executive board member, who described how online participation can make it easier for older members to participate:

"Online participation is one way to improve inclusion. For example, we have older people who are less mobile who could participate through this route."

It is important to note that none of these persons considered themselves 'old', 'digitally illiterate' or 'immobile' - they described what they thought members who were in these categories would experience. This is a theme that is visible through all interviews and observations: There are many expectations of what online participation will do to enable or inhibit "others" participation - groups that the members who made these comments do not belong to themselves. Some of these groups are likely to not have strong online habits, such as the elderly, women, parents, or persons with disabilities [12],
[18]. It seems unlikely that their habits would change simply because new tools are available.

This effect is particularly interesting where it happens in opposing directions. This is the case for example between the party leadership and grass-roots: A grass-roots member was convinced that online methods would be beneficial for the party leadership:

"There are networks where you can communicate in line with the statutes, where the executive board can network with the state boards, where only selectively, people have access based on their roles within the party."

On the other hand, the executive board is very interested in introducing new and more online participation methods because of the conviction that it will make it easier for grass-roots members to participate:

"We want to develop more tools so that everyone
can discuss online and offline, all members can
participate who currently cannot get involved through
the classic party structure." [Comment of an executive
board member at the assembly in Münster]

The same effect applies to factors like age, where older members think that online participation methods are particularly relevant to the next generation:

"I am not a person with a deficit in participation. (...) There's others, in the local branches, for example teenagers, or especially teenagers (...) There's a requirement. I don't have that requirement."

Participants without care responsibilities also expect that online participation will help those who have these responsibilities:

„Our assemblies always happen at children's” bedtime. It sounds trivial, but highly specifically excludes parents. For polls, discussions and so on, online participation would be really great."

And lastly, participants with plenty of time expect that online methods will help others who have limited availability due to their jobs:

"[Online Participation] is really good because it allows easy access independent of people's life and circumstances. For example, shift workers who work at night and can then go online and participate when they have the time."

These differences are particularly important, because they show how everyone thinks that online participation will be great - for somebody else. Although all participants were already actively using online platforms, these were taken for granted and not considered in any detail, while the expectations for future benefits for those who are not in this situation were very high indeed. While participants also saw the risk of potential exclusion through online processes, the expected benefits outweighed the possible constraint, which was also considered to be dealt with by offering alternative routes (such as sending letters instead of emails). 


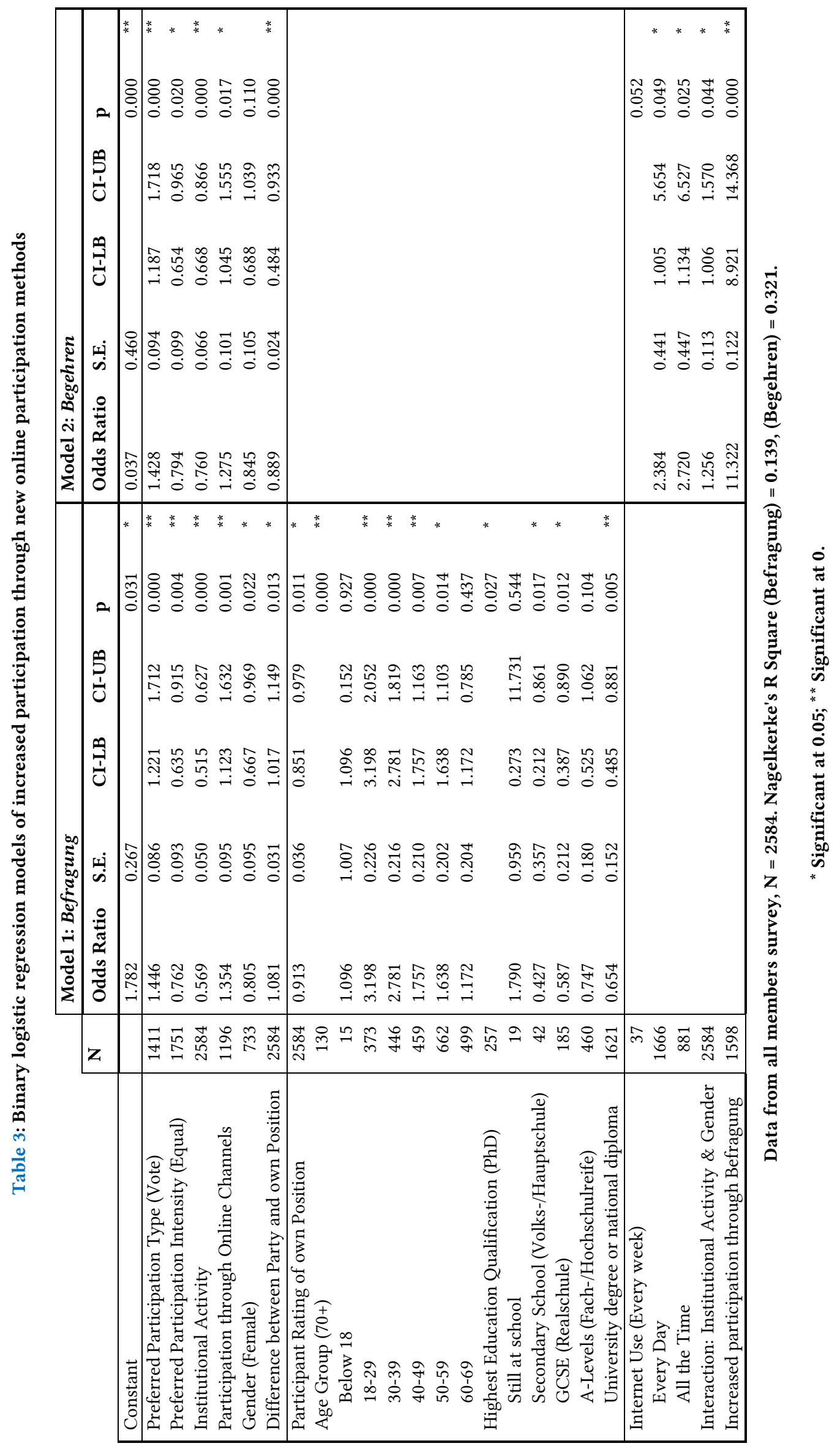




\subsection{What members expect to do}

The statistical analysis of our survey data suggests that the likelihood for members to increase their own participation through the new online methods varies, following at least some of the expected lines of the digital divide - age, education, gender [15], [45] - and not the expectations of the 'others' discussed above. Both models share a set of significant predictors, with some other predictors being significant for only one of the models.

\subsubsection{Demographics.}

Participants Age and Education were only significant predictors for anticipated increased participation through the Befragung. The younger members are, the more likely they are to state that they will increase their participation, with members between 18 and 29 being more than three times as likely to state this than members above 70 . Members between 40 and 59 years are still twice as likely to say they will participate more. This is in line with the digital divide literature, which suggests that online participation methods are primarily used by the younger generations [45].

This age difference also shows in education, where members who are still at school are 1.8 times as likely to say they will participate more than members with $\mathrm{PhDs}$. There is a clear direction in the type of degree members have: the higher the degree, the more likely they are to state that they will participate more online, with (among members who have completed school) those with $\mathrm{PhDs}$ being the most likely to say they will increase their participation. Members with lower qualifications (Secondary School / GCSE / lower university degrees) are between 0.4 and 0.7 times as likely to say they will participate more as those with $\mathrm{PhDs}$. This is again in line with the digital divide, as higher education indicates both more activity and benefit online, as well as more political engagement [15], [16].

Members who use the internet every day are more than twice as likely to say they will increase their participation through the Begehren as those who only use it on a weekly basis. However, there are very few participants who use the internet that rarely. While this is in line with current internet usage rates in broader society [46], the sample might be biased towards members who are already active online, e.g. those who use the internet less are also less likely to have participated in the survey. In addition to members already using the internet to participate in party processes, this can nevertheless be seen as further evidence that those who are already familiar with the internet are more likely to use it to their own advantage, and as such supports the reinforcement theory [12], [23].

Women are only 0.8 times as likely to say they will participate more with the Befragung as men. This corresponds to the digital divide literature, where women are still less likely to use the internet and engage in political activity online [45], as well as women's overall lower participation and representation in politics [20]. Moreover, it also corresponds to participation in the actual survey - which was part of a Befragung - where only $30 \%$ of respondents were women.

While there are certainly other factors that would justify distinction (e.g. race, class), gender is particularly important in the Green Party, as gender equality is one of their founding principles. Given these roots, and members' high expectations for gender equality, this result is both surprising and disturbing. The party has solid processes to ensure equal participation offline - such as quotas for all elections, or speaker lists that prioritise women but no such process for online participation methods. Women are not specifically encouraged to engage online, which makes it little surprising that the gender divide that still prevails in society at large [45] is reflected in their internal participation. However, literature suggests that their participation might increase over time [13] - this will again be monitored in future surveys.

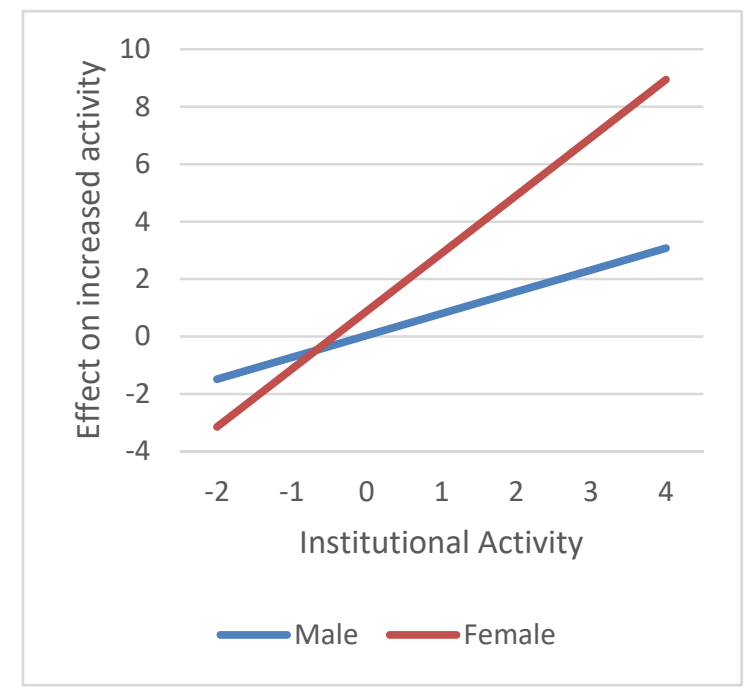

Figure 1: Interaction between Institutional Activity and Gender

There is however an interaction effect between institutional activity and gender on anticipated increased activity through the Begehren: Less active women are less likely to say they will increase their participation than comparably active men, while more active women are more likely to say they will increase their participation than comparably active men. Potentially being active increases women's confidence to participate more in other areas as well; or those who are already more confident become more active, to the same effect. Which of these is the cause does not matter as much as the effect in itself: Once women are active, they do participate, and they intend to do more.

The place of residence, whether members live in West or East Germany, and particularly whether they live in cities or the countryside, had no significant influence on their participation intention with either of the tools. This points to either a bias in the sample (those who would not participate more might not have participated in the survey), or there simply is no difference between residence areas, which would be unexpected given the digital divide literature [12]. Whether one or the other is the case might be explored in a future survey which includes a group of members who are not communicating with the party online. For now we can say that among this sample, where members live does not make a difference to whether they are planning to participate more online or not. 


\subsubsection{Current Participation}

Whether members already participate through online channels is a positive predictor for anticipated increased participation through both tools, with members who are already using online tools being 1.4 times as likely to anticipate an increase in participation through the Befragung as those who do not, and 1.3 times through the Begehren. This is little surprising in itself. After all, why would members who are already online not participate? However, this does point to the risk the party is taking by assuming that online participation will mobilise currently inactive members: If those who are already engaging with the party online are more likely to increase their participation than those who are not, then these groups' opinions will likely be reinforced [23].

Institutional Activity - the factor score described above - is a negative predictor for both the Befragung and Begehren: Members who are more active in the parties' established institutions are 0.6 times as likely to say they will increase their participation through the Befragung and 0.8 times as likely to do so through the Begehren as less active members. This is likely due to the fact that with them already being very active, there simply is not much room for them for an increase in activity, while for less active members, the new methods allow them to do more with a low threshold. The results for the Begehren in particular are consistent with the interviews: Those who already have positions have more direct connections with the executive board and thus have less need for the Begehren - they can simply ask the board directly, and expect a response. This points to a likely mobilisation effect, with new members being drawn into active participation [7].

\subsubsection{Political Orientation}

Political orientation measured on a 1-11 scale of political orientation (Left (1) to Right (11)) is commonly used by German political research institute Infratest dimap. This is loosely associated with the party wings [35], with the Linke positioning left of the Reformer, but neither being expected on the right $(>6)$ of the spectrum [47]. We used members' own position, and the difference between where members positioned themselves and the party on the same spectrum.

Members who position themselves further right on the political spectrum are 0.9 times as likely to say they will increase their own participation through the Befragung as those further to the left. However, if they position themselves right of where they see the party, this effect reverses, and they are instead 1.1 times as likely to say they will participate more. This is different for the Begehren: Members who position themselves further right than the party are 0.9 times as likely to say they will increase their participation through as those who position themselves the other way around. This change of direction is the only distinct difference between the two models, and there does not appear to be a substantial reason for that. The link between political orientation and online activity will be a focus in future analysis.

\subsubsection{Participation Preferences}

The preferred participation 'Type' and 'Intensity' are about equally strong predictors for both models, with members preferring participation through votes being 1.4 times as likely to say they would increase their participation through either tool as members who prefer discussions.

This is also a theme that arose during the interviews: The Befragung is seen as a good way for the party leadership to gather large scale feedback from the grass-roots, but some members see a danger that there will not be sufficient discussion before these surveys take place. Members who prefer votes plan to add their voice to the type of engagement that bears most similarity to a vote, while those preferring discussions do not.

Members who favour equal over most possible participation on the other hand are only 0.8 times as likely to say they will increase their participation through the new online tools as those with the opposite preference. Members who think everyone should participate as much as possible are more likely to say they will increase their participation through both methods. This is also consistent with the qualitative data: Where members were sceptical about online systems, this largely referred to the systems' performance against the parties' ideal of equality.

\subsubsection{Anticipated participation through Befragung}

The strongest predictor for an anticipated increase in participation through the Begehren is whether members intend to participate more through the Befragung. Those who do are 11.3 times as likely to say they will participate more through the Begehren, too. This can likely be ascribed to a general willingness to engage with online participation methods. Since both tools are new and have no equivalent (offline) processes, it seems sensible that members assume they will either use both or none.

This might however point to a lack of understanding of the purpose of the tools: The Befragung will be conducted by the executive board, and as such the process (though not the result) very much functions top-down: the board decides about the topic, the questions, the timeline, and all members need to do is respond when they get an email invitation. The federal executive board has an obligation, embedded in the initial decision to introduce the Befragung, to hold them regularly. This looks very different for the Begehren, which is very much a bottom-up process. It will not become active unless the grass-roots make it happen. Begehren can be started or supported by all members, with the expectation that it will be a tool for the grass-roots to bring topics onto the agenda of the executive board. However, if there are no members willing to start the process and collect supporters, there is no automatism by which members can engage in this way.

\subsubsection{Differences between Befragung and Begehren}

The model for increased participation through the Begehren looks very different compared to the one for the Befragung. The digital divide does not show here: Neither age nor gender or education were significant predictors for an anticipated increase in participation. Instead, those who are online more regularly, and already participate through online channels, are more likely to say they will participate more in the Begehren. These results are likely due to the fact that members - neither at grass roots nor at leadership level - know how the Begehren can or will be used. It does not relate to any process they are familiar with, and therefore they are unsure what to expect.

\section{CONCLUSIONS}

The new online participation tools that the Green Party introduces raise hopes of including more members in participation processes. Party members of all ranks believe that with the introduction of new online participation methods there should be more people willing to engage, more things to do, a 
broader group of members involved, and those who are currently not engaging will have another opportunity to become involved. At the same time, existing participation online appears to be so seamless that current advantages are hardly recognised.

Both hopes and expectations are that the new online tools will have a mobilising effects. Our results indicate that this is unlikely. Even though members expect all kinds of benefits, especially for their less-privileged peers, the Befragung appears to be unable to overcome the social and digital divide: Members who are better off, better educated, and already more active, will benefit more than those the party hopes to engage. Reinforcement is a more likely result of the introduction of the Befragung than mobilisation.

This is different for the Begehren, which does not reflect the digital or participation divide - neither gender nor age or education are significant predictors for an anticipated increase in participation. This offers cause for hope, as the Begehren might indeed be a tool that overcomes existing divides, both digital and participation, and even between the party 'elite' and grass-roots. The fact that active women intend to become even more active online with the Begehren is particularly promising, because this also means that if the party can manage to encourage women to participate either online or offline, they are likely to be mobilised further.

The literature on participation and the digital divide tells us that there are still clear distinctions in terms of who participates, and to which effect: Social class, available resources and time, gender and education all play a role in determining how likely a person is to be active, both politically and on the internet. All of this is likely to occur with the Befragung in the Green Party. This is problematic for the party, as - though the goal of increasing participation may be met - the goal of holding participation equal will likely not be. Even if more participation happens, it will be 'more of the same*.

In practical terms, there might be room to re-think some of the processes in order to change this, for example by introducing quotas or such for a balance in gender, or by specifically addressing and supporting those members that are currently underrepresented. For example, the party could develop methods to increase women's participation online that correspond to the processes they use offline. They could also offer explicit training across their member base, to increase their skills and thus confidence to participate.

\section{FUTURE WORK}

The major limitation of this paper is that the data, and the predicted variables - an anticipated increase in participation through different new online participation methods - is only based on what members say they will do. This will not necessarily happen. The next step will therefore be to actually measure the change in participation across the introduction of these new online participation tools, and see whether what members say they will do will actually come to pass.

\section{ACKNOWLEDGEMENTS}

This research was funded by the EPSRC Centre for Doctoral Training in Web Science Innovation, EP/L016117/1. Funding for fieldwork was supplemented by the Green Party Germany.

We are grateful to our interview partners, and to all those who responded to our survey, for their participation in this study. We would like to thank the Green Party Germany, especially general secretary Michael Kellner, and head of members' participation Thomas Künstler, for their extensive and continued support of this project.

None of the authors are members of the party, and the party had no influence on the analysis and conclusions drawn.

\section{REFERENCES}

[1] G. C. N. Smith, Democratic innovations: designing institutions for citizen participation. Cambridge University Press, 2009.

[2] P. Aragón et al., "When a Movement becomes a party," 2013.

[3] A. Kolleck, "Kommunale Online-Beteiligung: Stand und Herausforderungen kommunaler Bürgerbeteiligung.,” Der Bürger im Staat, vol. 64, no. 4, pp. 238245, 2014.

[4] M. Cantijoch, D. Cutts, and R. Gibson, "Moving Slowly up the Ladder of Political Engagement: A 'Spill-over' Model of Internet Participation,” Br. f. Polit. Int. Relations, vol. 18, no. 1, pp. 26-48, Feb. 2015.

[5] A. Michels and L. De Graaf, "Examining Citizen Participation: Local Participatory Policy Making and Democracy," Local Gov. Stud., vol. 36, no. 4, pp. 477-491, 2010.

[6] M. E. Morrell, "Deliberation, democratic decision-making and internal political efficacy,” Polit. Behav., vol. 27, no. 1, pp. 49-69, 2005.

[7] P. Norris, Digital Divide: Civic Engagement, Information Poverty, and the Internet Worldwide. Cambridge: Cambridge Universiy Press, 2001.

[8] R. Gibson, W. Lusoli, A. Römmele, and S. J. Ward, "Introduction: representative democracy and the Internet," Electron. Democr. mobilisation, Organ. Particip. via new ICTs, vol. 33, pp. 1-16, 2004.

[9] S. Boulianne, "Does Internet Use Affect Engagement? A Meta-Analysis of Research,” Polit. Commun., vol. 26, no. 2, pp. 193-211, 2009.

[10] S. Vissers, M. Hooghe, D. Stolle, and V.-A. Maheo, "The Impact of Mobilization Media on Off-Line and Online Participation: Are Mobilization Effects MediumSpecific?," Soc. Sci. Comput. Rev., vol. 30, no. 2, pp. 152-169, 2012.

[11] K. Gerl, S. Marschall, and N. Wilker, "Does the Internet Encourage Political Participation? Use of an Online Platform by Members of a German Political Party," Policy and Internet, vol. 10, no. 1, pp. 87-118, 2018.

[12] G. Vowe, "Digital Citizens und Schweigende Mehrheit: Wie verändert sich die politische Beteiligung der Bürger durch das Internet? Ergebnisse einer kommunikationswissenschaftlichen Langzeitstudie," in Internet und Partizipation, no. Mpfv 2011, Wiesbaden: Springer Fachmedien Wiesbaden, 2014, pp. 25-52.

[13] A. Kerr and J. Waddington, "E-Communications: An Aspect of Union Renewal or Merely Doing Things Electronically?," Br. f. Ind. Relations, vol. 52, no. 4, pp. 658-681, Dec. 2014

[14] Eurostat, "Privathaushalte, die einen Breitbandzugang haben," 2017. [Online] Available:

http://ec.europa.eu/eurostat/tgm/table.do?tab=table\&init=1\&language=de\&pco $\mathrm{de}=$ tin00073\&plugin=1\&tableSelection=1. [Accessed: 24-Jan-2018].

[15] E. Hargittai, "The Digital Reproduction of Inequality," in Social Stratification, D. Grusky, Ed. Boulder, CO: Westview Press, 2008, pp. 936-944.

[16] E. Ferro, J. R. Gil-Garcia, and N. Helbig, "The digital divide metaphor: understanding paths to IT literacy," in Electronic Government, Springer, 2007, pp. 265-280.

[17] S. Halford and M. Savage, "Reconceptualizing Digital Social Inequality," Information, Commun. Soc., vol. 13, no. 7, pp. 937-955, Oct. 2010.

[18] A. Quan-Haase, K. Martin, and K. Schreurs, "Interviews with digital seniors: ICT use in the context of everyday life," Information, Commun. Soc., vol. 4, no. 5, 2016.

[19] T. Spier, M. Klein, U. Von Alemann, H. Hoffmann, A. Laux, and A. Nonnenmacher, Parteimitglieder in Deutschland. Wiesbaden: VS Verkag für Sozialwissenschaften. 
[20] B. Busse, A. Hashem-Wangler, and J. Tholen, "Two worlds of participation: young people and politics in Germany," Sociol. Rev., vol. 63, no. 1958, pp. 118140, 2015.

[21] R. Dahl, Democracy and its Critics. Yale University Press, 1989.

[22] M. Margolis, D. Resnick, and C.-C. Tu, "Campaigning on the Internet - Parties and candidates on the World Wide Web in the 1996 primary season," Harvard Int. F. Press., vol. 2, no. 1, pp. 59-78, 1997.

[23] W. Lusoli, S. Ward, and R. Gibson, "Political organisations and online mobilisation: Different media - same outcomes?," New Rev. Inf. Netw., vol. 8, no. 1, pp. 89-107, Jan. 2002.

[24] S. Ward, R. Gibson, and W. Lusoli, "Online Participation and Mobilisation in Britain: Hype, Hope and Reality,” Parliam. Aff., vol. 56, no. 4, pp. 652-668, Oct. 2003.

[25] J. L. Jensen, "Political Participation Online: The Replacement and the Mobilisation Hypotheses Revisited," Scan. Polit. Stud., vol. 36, no. 4, pp. 347-364, Dec. 2013.

[26] B. C. Reisdorf and D. Groselj, "Internet (non-)use types and motivational access: Implications for digital inequalities research," New Media Soc., vol. 19, no. 8, pp. 1157-1176, 2017.

[27] S. Wyatt, "Non-users also matter. The construction of users and non-users of the internet," in How users matter. The co-construction of users and technologies, no. January 2003, 2003, pp. 67-80.

[28] C. Lutz and C. P. Hoffmann, "The dark side of online participation: exploring non-, passive and negative participation," Information, Commun. Soc., vol. 20 no. 6, pp. 876-897, 2017.

[29] L. Heimrich, "Parteien digital: Mitgliederkommunikation im Zeitalter des Internets," Technische Universität Ilmenau, 2013.

[30] R. Heinrich and M. Spitz, "Relevanz gewinnt - Online-Partizipation im Wahlkampf bei den Grünen!," in Internet und Partizipation, Wiesbaden: Springer Fachmedien Wiesbaden, 2014, pp. 223-236.

[31] Germany, Basic Law for the Federal Republic of Germany (Grundgesetz für die Bundesrepublik Deutschland). 2010.

[32] Germany, Political Parties Act. Translation as of 15 March 2009. Germany, 2004.

[33] K.-R. Korte, "So entscheiden Parteien: Umfeld-Bedingungen innerparteilicher Partizipation," Wie Entscheid. Parteien? Prozesse Inn. Willensbildung Deutschl. (ZPol Sonderband 2012), pp. 267-286, 2012.

[34] E. G. Frankland, "The Evolution of the Greens in Germany: From Amateurism to Professionalism," in Green Parties in Transition: The End of Grass-Roots Democracy?, E. G. Frankland, P. Lucardie, and B. Rihoux, Eds. Farnham, Surrey: Ashgate, 2008, pp. 19-42.

[35] N. Switek, "Bündnis 90/ Die Grünen: zur Entscheidungsmacht grüner Bundesparteitage," in Wie entscheiden Parteien? Prozesse innerparteilicher Willensbildung in Deutschland (ZPol Sonderband 2012), K.-R. Korte and J. Treibel, Eds. Baden-Baden: Nomos, 2012, pp. 121-154.

[36] Bündnis 90 / Die Grünen, "Grüne Regeln (Satzung).” p. 91, 2015.

[37] U. von Alemann and A. Laux, "Die Mitglieder als Faktor innerparteilicher Willensbildung und Entscheidungsfindung," in Wie entscheiden Parteien Prozesse innerparteilicher Willensbildung in Deutschland, ZPol Zeitschrift für Politikwissenschaft, Sonderband 2012, K.-R. Korte and J. Treibel, Eds. BadenBaden: Nomos, 2012, pp. 249-266.

[38] R. Heinrich, M. Lübker, and H. Biehl, "Parteimitglieder im Vergleich: Partizipation und Repräsentation," Potsdam, 2002.

[39] M. Kellner, "Beteiligungspartei 2019," 2015.

[40] B. Flyvbjerg, "Five Misunderstandings About Case-Study Research," Qual. Inq., vol. 12, no. 2, pp. 219-245, 2006.

[41] M. Kellner, "Task Force Beteiligung." 2014.

[42] M. Q. Patton, "Enhancing the quality and credibility of qualitative analysis.," Health Serv. Res., vol. 34, no. Patton 1990, pp. 1189-1208, 1999.

[43] V. A. Anfara, K. M. Brown, and T. L. Mangione, "Qualitative Analysis on Stage: Making the Research Process More Public," Educ. Res., vol. 31, no. 7, pp. 28-38, 2002.

[44] A. Field, Discovering Statistics Using IBM SPSS Statistics, 4th Editio. SAGE Publications, 2013.

[45] M. Emmer, G. Vowe, and J. Wolling, Bürger online: die Entwicklung der politischen Online-Kommunikation in Deutschland. Konstanz: UVK Verlagsgesellschaft, 2011.

[46] Statistisches Bundesamt (Destatis), “Häufigkeit der Internetnutzung 2017,” 2017. [Online]. https://www.destatis.de/DE/ZahlenFakten/GesellschaftStaat/EinkommenKons umLebensbedingungen/_Grafik/ITNutzung_Haeufigkeit.png?_blob=poster. [Accessed: 28-Mar-2018].

[47] W. Rudzio, Das politische System der Bundesrepublik Deutschland. Wiesbaden: Springer Fachmedien Wiesbaden, 2015. 